\title{
DÜBLIN
}

Technological University Dublin

ARROW@TU Dublin

\section{Improved Nitrate Sensing using Ion Selective Electrodes Based on Urea-Calixarene Ionophores}

\author{
Benjamin Schazmann \\ Technological University Dublin, benjamin.schazmann@tudublin.ie \\ Dermot Diamond \\ Dublin City University
}

Follow this and additional works at: https://arrow.tudublin.ie/scschcpsart

Part of the Analytical Chemistry Commons, Environmental Chemistry Commons, Materials Chemistry Commons, Organic Chemistry Commons, and the Physical Chemistry Commons

\section{Recommended Citation \\ Schazmann, B. \& Diamond, D.(2007) Improved Nitrate Sensing using Ion Selective Electrodes Based on Urea-Calixarene lonophores New Journal of Chemistry, 31, 587-592. DOI: 10.1039/b702841p}

This Article is brought to you for free and open access by the School of Chemical and Pharmaceutical Sciences at ARROW@TU Dublin. It has been accepted for inclusion in Articles by an authorized administrator of ARROW@TU Dublin. For more information, please contact arrow.admin@tudublin.ie, aisling.coyne@tudublin.ie, gerard.connolly@tudublin.ie.

Funder: Enterprise Ireland, grant code SC/2002/161, Science Foundation Ireland for support under the Adaptive Information Cluster award (SFI03/IN3/1361) and the Environmental Protection Agency, Ireland, funding code EPA2004-RS-AICM4.

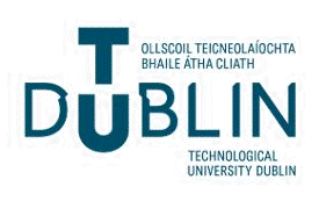




\title{
Improved nitrate sensing using ion selective electrodes based on urea-calixarene ionophores
}

\author{
Benjamin Schazmann* and Dermot Diamond* \\ Received (in Montpellier, France) 23rd February 2007, Accepted 26th February 2007 \\ First published as an Advance Article on the web \\ DOI: $10.1039 / \mathbf{b 7 0 2 8 4 1 p}$
}

10

Urea-calix[4]arenes $\mathbf{1}$ and $\mathbf{2}$ were synthesised and incorporated into ISE membranes for assessment as sensors for inorganic anions in water. $\mathbf{1}$ revealed a strong response to all anions following the Hofmeister selectivity order. For ISEs of $\mathbf{2}$, the response to a portion of the anion series was suppressed, increasing the margin of selectivity of nitrate over chloride, a common interferant of nitrate in fresh and marine water samples. The performance of ISEs containing 2 was compared to commercially available alkylammonium nitrate ion-exchange salts used for nitrate sensing. Our ISEs performed favourably in terms of sensitivity, linear range and LOD with an improved selectivity coefficient over chloride of $\log K_{\mathrm{NO}_{3}^{-} \mathrm{Cl}^{-}}{ }^{\text {pot }}$ of -3.4 , an order of

20 magnitude better than commercially available nitrate ISEs. The pre-conditioning of ISEs in nonprimary chloride salt was essential for obtaining these results.

\section{Introduction}

25 The earliest potentiometric ion selective electrode (ISE) sensors were based on ion-exchange alone. For example, the common glass electrode for measuring $\mathrm{pH}$ has been around for about 90 years. ${ }^{1}$ This electrode is based on the reversible binding of protons to silanol groups $\left(-\mathrm{SiO}^{-} \mathrm{H}^{+}\right)$and thereby 30 indicates the $\mathrm{pH}$ of an aqueous sample. However, electrodes based on ion-exchange alone tend to suffer from considerable interference from other ions. In the case of the $\mathrm{pH}$ electrode, some interference from monovalent cations may be encountered, resulting in the 'alkali error'.

By the 1970s, the concept of incorporating an ion-exchange salt and an ionophore within a plasticized, flexible PVC membrane had become popular. ${ }^{2}$ In the case of neutral ionophores, they usually comprise carefully preorganised structures, which selectively and reversibly bind the analyte via preorganisation or a best-fit size-exclusion principle. In this way, far more selective and useful responses can be achieved than based on ion-exchange alone. Successful cation selective ionophore-based ISEs soon emerged such as the calcium selective ISEs of Simon and co-workers ${ }^{3,4}$ and a potassium selective ISEs based on valinomycin ${ }^{5,6}$ used for blood serum analysis. Our own group has synthesised numerous calixarene based macrocyclic ionophores and incorporated these into ISEs, achieving good selectivities for cations including sodium, ${ }^{7}$ calcium,${ }^{8}$ lead, ${ }^{9}$ europium, ${ }^{10}$ lithium ${ }^{11}$ and mercury. ${ }^{12}$

50 However, in the field of ISEs, there are far fewer successful anion sensing systems reported, largely due to competitive solvent effects. ${ }^{13,14}$ In water-based sensing it is more difficult to overcome the dominant exchange-extraction mechanism based on ion lipophilicity for anions in particular, which leads

Adaptive Sensors Group (ASG), National Centre for Sensor Research (NCSR), Dublin City University, Dublin 9, Ireland. E-mail:

Dermot.Diamond@dcu.ie,Benjamin.Schazmann2@mail.dcu.ie; Fax: 00353 1 7007995; Tel: 0035317005670 to a Hofmeister order of response: $\mathrm{ClO}_{4}{ }^{-}>\mathrm{SCN}^{-}>\mathrm{NO}_{3}{ }^{-}$ $\left.>\mathrm{I}^{-}>\mathrm{Br}^{-}>\mathrm{Cl}^{-}>\mathrm{F}^{-}>\mathrm{HCO}_{3}{ }^{-}>\mathrm{SO}_{4}{ }^{2-}\right) .{ }^{13}$ The ionic size to charge ratio dictates the size of the ion hydration layer/ lipophilicity. The ionophore must be able to generate interactions with the target ion of greater magnitude than the hydration energy, to make binding thermodynamically favourable. The ion-exchanger influence in an ISE can therefore override the presence of a carefully designed anion host or preorganised ionophore. In contrast, the cation selective ISEs referred to above all using ion-exchange salts and ionophores, often behave in a non-Hofmeister fashion with unambiguous selectivities.

Calixarenes, including $\mathbf{1}$ and $\mathbf{2}$, are a class of supramolecular receptor. Since their description by Gutsche in the 1980s, ${ }^{15}$ many calixarene derivatives have been described, due to the ease of modification of the so called upper (wide) and lower (narrow) rims of the calixarene's central annulus. ${ }^{16-21}$ This has lead to rigid pre-organised compounds, which can encapsulate specific analytes via well-defined size-compatibility. The cavities are lined with appropriately orientated functional groups to reversibly bind guests in a non-covalent manner.

The (thio)urea functional group is the group of choice in neutral anion selective hosts. Nature favours (thio)ureas; for example sulfate and phosphate proteins are vital receptors for active transport systems in cells and specific binding takes place invariably through hydrogen bonding groups such as ureas. ${ }^{22,23}$ Furthermore, the bonds are highly directional and so suitable for designing hosts for anions, which can have a large variety of geometries. ${ }^{13}$ The field of supramolecular chemistry contains examples of larger cyclic structures containing cavities adorned with urea functionalities, such as cyclophanes ${ }^{24,25}$ and calixarenes. ${ }^{26-37}$

There are examples of calixarene-urea ionophores that have been examined in ISEs for anion sensing. ${ }^{37}$ There are also noncalixarene urea-based potentiometric sensors for anions such as chloride, ${ }^{38}$ sulfate ${ }^{39}$ and hydrogen sulfite selective systems. ${ }^{40}$ 
1 Table 1 Typical dissolved major anion concentrations in river water in an industrialised country (source: US geological survey)

\begin{tabular}{lrl}
\hline Ion & $\mathrm{Wt} \%$ & Concentration $/ \mathrm{mol} \mathrm{l}^{-1}$ \\
\hline Hydrogencarbonate $\left(\mathrm{HCO}_{3}{ }^{-}\right)$ & 48.7 & $1 \times 10^{-3}$ \\
Sulfate $\left(\mathrm{SO}_{4}{ }^{--}\right)$ & 9.3 & $1.2 \times 10^{-4}$ \\
Chloride $\left(\mathrm{Cl}^{-}\right)$ & 6.5 & $2.2 \times 10^{-4}$ \\
Nitrate $\left(\mathrm{NO}_{3}{ }^{-}\right)$ & 0.8 & $1.5 \times 10^{-5}$ \\
Total & 100 &
\end{tabular}

10 The analysis of nitrate is of major importance in the field of anion sensing. Nitrate monitoring is crucial in freshwater sources such as groundwater, rivers and also at sea. Although essential as a plant nutrient for example, pollution and adverse health effects can result from excessive anthropogenic nitrate input. This may include fertiliser run-off from fields and animal waste and decay.

In ion selective electrodes (ISEs), $\operatorname{tri}^{-41}$ and tetra ${ }^{42}$ dodecylmethylammonium nitrate ion-exchange salts remain the basis for potentiometric nitrate sensing. $\dagger$ These salts function

20 within the membrane as ion-exchange salts and they obviously do not have much structural pre-organisation or steric properties leading to unique selectivities. It is little surprise therefore that the selectivities of these ISEs approximately follow a Hofmeister response pattern. ${ }^{43}$ It is the fact that nitrate appears high in the Hofmeister series relative to chloride (which is the main interferant for nitrate in typical freshwater samples), that renders the ISEs somewhat useful for nitrate sensing. Commercially available nitrate ISEs typically quote $\mathrm{SCN}^{-}, \mathrm{Br}^{-}, \mathrm{I}^{-}$and $\mathrm{ClO}_{4}^{-}$as major interferants. $\ddagger$ Such ISEs

30 are not truly nitrate selective. Table 1 shows typical riverine major anion concentrations in an industrialised country. ${ }^{44}$ These concentrations can, of course, vary considerably.

The anions most proximal to nitrate in the Hofmeister series, due to their (assumed) absence or negligible presence, 35 are not deemed to impair the ability to detect true nitrate concentrations. It is in this context that today's commercial nitrate ISEs are applied.

The presence of urea-calixarene ionophores in addition to ion-exchange salt within ISE membranes is investigated here,

40 with the goal of improving ISE parameters like linear range, LOD and selectivity towards nitrate.

\section{Experimental}

\section{Reagents}

All reagents used for electrochemistry were analytical grade. Doubly distilled de-ionised water was used in all cases.

50 Methanol, acetonitrile (ACN) and dry tetrahydrofuran (THF) used were HPLC grade. High molecular weight poly(vinyl chloride) PVC was used. Sodium anion salts were used. All organic reagents were reagent grade or better. All chemicals were supplied by Fluka.

55

$\dagger$ Sigma-Aldrich (www.SigmaAldrich.com): tri- and tetra-dodecylmethylammonium nitrate. [13533-59-0] and [63893-35-6], respectively. $\ddagger$ Examples include the ELIT8021 from nico2000 (www.nico2000.net) and the nitrate ISE from Vernier Software and Technology (www.Vernier.com)
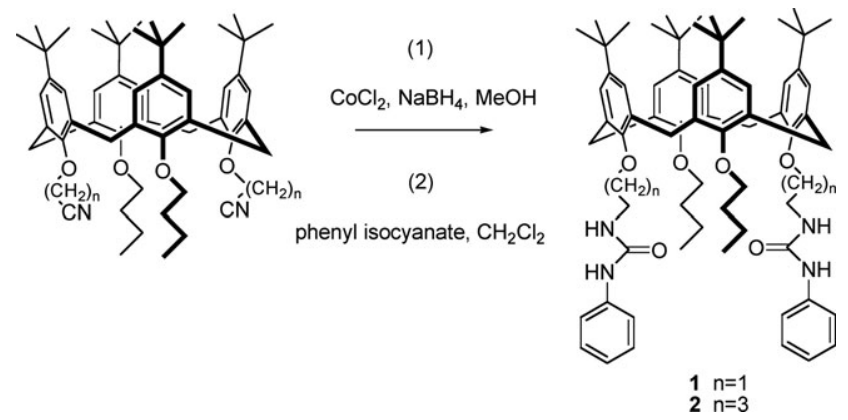

1

Scheme 1

Synthesis of calixarene ionophores 1 and 2

The synthesis of di-urea calix[4]arenes $\mathbf{1}$ and $\mathbf{2}$ was performed according to Scheme 1.

$5,11,17,23$-Tetra-p-tert-butyl-25,27-bis $\left[\mid\left(N^{\prime}\right.\right.$-phenylureido)butyl]oxy]-26,28-dibutoxycalix[4]arene (2). $\mathrm{CoCl}_{2} \cdot 6 \mathrm{H}_{2} \mathrm{O}(0.64 \mathrm{~g}$, $2.7 \mathrm{mmol}$ ) was heated at $200{ }^{\circ} \mathrm{C}$ for $20 \mathrm{~min}$ to produce blue dehydrated $\mathrm{CoCl}_{2}$. This was stirred under argon in $7 \mathrm{ml}$ $\mathrm{MeOH}$ for $15 \mathrm{~min}$. Starting calix[4]arene ${ }^{45}(0.3 \mathrm{~g}, 0.34 \mathrm{mmol})$ was added to the suspension. $5 \times 0.1 \mathrm{~g}$ batches of $\mathrm{NaBH}_{4}(0.5$ $\mathrm{g}, 13.4 \mathrm{mmol}$ ) were added on an hourly basis and the mixture stirred at room temperature for $24 \mathrm{~h} . \mathrm{NaBH}_{4}(0.5 \mathrm{~g}, 13.4$ $\mathrm{mmol}$ ) was added batchwise again and the mixture left for a further $24 \mathrm{~h} .20 \mathrm{ml}$ of $\mathrm{CH}_{2} \mathrm{Cl}_{2}$ were added and $3 \mathrm{M} \mathrm{HCl}$ until the suspended black solid was largely dissolved. $25 \% \mathrm{NH}_{3}$ was added until the solution turned basic. The solution was extracted with $\mathrm{CH}_{2} \mathrm{Cl}_{2}(3 \times 20 \mathrm{ml})$. The combined organic layers were washed with $20 \mathrm{ml}$ water and $20 \mathrm{ml}$ brine and dried with $\mathrm{Na}_{2} \mathrm{SO}_{4}$. Upon evaporation of the solvent, $0.1 \mathrm{~g}$ of an oily solid remained. This was placed into $2 \mathrm{ml}$ chloroform and phenyl isocyanate added $(60 \mu \mathrm{l}, 0.55 \mathrm{mmol})$. The resulting clear brown solution was left stirring under argon for $12 \mathrm{~h}$. Into the clear green solution, $3 \mathrm{ml}$ water was added to give a brown emulsion. The organic layer was extracted with chloroform $(3 \times 10 \mathrm{ml})$, washed with water $(10 \mathrm{ml})$ and brine $(10 \mathrm{ml})$ followed by drying with $\mathrm{Na}_{2} \mathrm{SO}_{4}, 0.1 \mathrm{~g}$ of a brown oil remained. LC-MS analysis of the product revealed this crude to consist of $37.6 \% 2.22 .7 \mathrm{mg}$ of a white solid were recovered by semi-preparative HPLC (SP-HPLC), representing an LC recovery yield of $60.4 \%$ and an overall yield of $5.8 \% 2 ; \mathrm{mp}$ 245-247 ${ }^{\circ}$ C. Anal. Calc. for $\mathrm{C}_{74} \mathrm{H}_{100} \mathrm{~N}_{4} \mathrm{O}_{6}$ : C 77.85, H 8.83, N 4.91. Found: C 77.80, H 8.79, N 4.83\%. $\nu_{\max }\left(\mathrm{KBr}\right.$ disc) $/ \mathrm{cm}^{-1}$ $3338,1645 . \delta_{\mathrm{H}}\left(400 \mathrm{MHz} ; \mathrm{CDCl}_{3} ; \mathrm{Me}_{4} \mathrm{Si}\right) 7.61(2 \mathrm{H}, \mathrm{m}, \mathrm{Ar} H)$, $7.15(4 \mathrm{H}, \mathrm{d}, \operatorname{Ar} H), 7.09(4 \mathrm{H}, \mathrm{s}, \operatorname{Ar} H), 6.09(4 \mathrm{H}, \mathrm{m}, \operatorname{Ar} H), 6.42$ $(4 \mathrm{H}, \mathrm{m}, \mathrm{Ar} H), 5.72(2 \mathrm{H}, \mathrm{s}, \mathrm{ArNHCO}), 5.65(2 \mathrm{H}, \mathrm{t}$, $\left.\mathrm{CON} \mathrm{HCH}_{2}\right), 4.33$ and $3.10\left(8 \mathrm{H}, \mathrm{ABq}, J=12.4, \mathrm{ArCH} \mathrm{H}_{2} \mathrm{Ar}\right)$, $3.94\left(4 \mathrm{H}, \quad \mathrm{t}, \quad \mathrm{CH}_{3}\left(\mathrm{CH}_{2}\right)_{2} \mathrm{CH}_{2} \mathrm{OAr}\right), \quad 3.80 \quad(4 \mathrm{H}, \quad \mathrm{t}$, $\left.\mathrm{NH}\left(\mathrm{CH}_{2}\right)_{3} \mathrm{CH}_{2} \mathrm{OAr}\right), 3.64\left(4 \mathrm{H}, \mathrm{m}, \mathrm{NHCH}_{2}\right), 3.39(4 \mathrm{H}, \mathrm{m}$, $\left.\mathrm{NHCH}_{2} \mathrm{CH}_{2}\right), 1.99\left(4 \mathrm{H}, \mathrm{m}, \mathrm{NH}\left(\mathrm{CH}_{2}\right)_{2} \mathrm{CH}_{2}\right), 1.81$ (4H, m, $\left.\mathrm{CH}_{3} \mathrm{CH}_{2} \mathrm{CH}_{2}\right), 1.45\left(4 \mathrm{H}, \mathrm{m}, \mathrm{CH}_{3} \mathrm{CH}_{2}\right), 1.29(18 \mathrm{H}$, s, tertbutyl), $0.90\left(6 \mathrm{H}, \mathrm{t}, \mathrm{CH}_{3} \mathrm{CH}_{2}\right), 0.82\left(18 \mathrm{H}, \mathrm{s}\right.$, tert-butyl). $\delta_{\mathrm{C}}$ $\left(50 \mathrm{MHz}, \mathrm{CDCl}_{3}\right)$ 151.2, 142.3, 132.5, 127.2, 117.3, 106.3, $105.1,97.1,64.1,32.1,29.8,23.1,22.4,18.6,16.2 \mathrm{ppm} . \mathrm{m} / \mathrm{z}$ 
1 (ESI) $1163.8\left(\mathrm{M}+\mathrm{Na}^{+}\right.$, requires 1163.8). HPLC purity: $98.1 \%$.

$5,11,17,23-T e t r a-p$-tert-butyl-25,27-bis $\left[\mid\left(N^{\prime}\right.\right.$-phenylurei-

5 do)ethyl]oxy]-26,28-dibutoxycalix[4]arene (1). Starting calix[4]arene $^{45}(0.40 \mathrm{~g}, 0.48 \mathrm{mmol})$ underwent $\mathrm{NaBH}_{4}$ reduction using an identical procedure as for the synthesis of $\mathbf{2}$. In this way, $0.27 \mathrm{~g}$ of a brown oily solid was obtained. This was placed into $8 \mathrm{ml}$ of chloroform and phenyl isocyanate $(175 \mu \mathrm{l}, 1.6 \mathrm{mmol})$

10 was added. The solution was left stirring under argon for $12 \mathrm{~h}$ and the work up proceeded as in the synthesis of 2. $0.18 \mathrm{~g}$ of a brown oil remained. LC-MS analysis of the product revealed this crude to consist of $29.0 \% \mathbf{1} .41 .2 \mathrm{mg}$ of a white solid were recovered by SP-HPLC, representing an LC recovery yield of

$1578.9 \%$ and an overall yield of $7.9 \% \mathbf{1}$; mp 258-260 ${ }^{\circ} \mathrm{C}$. Anal. Calc. for $\mathrm{C}_{70} \mathrm{H}_{92} \mathrm{~N}_{4} \mathrm{O}_{6}$ : C 77.45, $\mathrm{H}$ 8.54, N 5.16. Found: $\mathrm{C}$ 77.61, H 8.56, N 5.05\%. $\nu_{\max }(\mathrm{KBr}$ disc $) / \mathrm{cm}^{-1} 3343,1648 . \delta_{\mathrm{H}}$ (400 MHz; $\left.\mathrm{CDCl}_{3} ; \mathrm{Me}_{4} \mathrm{Si}\right) 7.45(2 \mathrm{H}, \mathrm{m}, \mathrm{Ar} H), 7.31(4 \mathrm{H}, \mathrm{d}$, $\operatorname{Ar} H), 7.08$ (4H, s, ArH), $6.92(4 \mathrm{H}, \mathrm{m}, \operatorname{Ar} H), 6.39(4 \mathrm{H}, \mathrm{m}$,

$20 \mathrm{ArH}), 5.60(2 \mathrm{H}, \mathrm{s}, \mathrm{ArNHCO}), 5.05\left(2 \mathrm{H}, \mathrm{t}, \mathrm{CONHCH}_{2}\right), 4.32$ and $3.11\left(8 \mathrm{H}, \mathrm{ABq}, J=12.4, \mathrm{ArCH}_{2} \mathrm{Ar}\right), 3.92(4 \mathrm{H}, \mathrm{m}$, $\left.\mathrm{NHCH}_{2}\right), 3.71\left(4 \mathrm{H}, \mathrm{t}, \mathrm{NHCH}_{2} \mathrm{CH}_{2} \mathrm{OAr}\right), 3.62(4 \mathrm{H}, \mathrm{t}$, $\left.\mathrm{CH}_{3}\left(\mathrm{CH}_{2}\right)_{2} \mathrm{CH}_{2} \mathrm{OAr}\right), 2.41\left(4 \mathrm{H}, \mathrm{m}, \mathrm{CH}_{3} \mathrm{CH}_{2} \mathrm{CH}_{2}\right), \quad 1.32$ (18H, s, tert-butyl), $1.22\left(4 \mathrm{H}, \mathrm{m}, \mathrm{CH}_{3} \mathrm{CH}_{2}\right), 0.88(6 \mathrm{H}, \mathrm{t}$,

$\left.25 \mathrm{CH}_{3} \mathrm{CH}_{2}\right), 0.74\left(18 \mathrm{H}, \mathrm{s}\right.$, tert-butyl). $\delta_{\mathrm{C}}\left(50 \mathrm{MHz}, \mathrm{CDCl}_{3}\right)$ 135.9, 132.1, 129.4, 124.9, 68.5, 34.2, 32.3, 30.0, 28.2, 24.2, $22.6,16.7,14.4$ ppm. $m / z$ (ESI) $1107.9\left(\mathrm{M}+\mathrm{Na}^{+}\right.$, requires 1107.7). HPLC purity: $97.6 \%$.

\section{Analytical and semi-preparative (SP) HPLC and mass} spectrometry (MS)

HPLC was carried out using a HP1100 with UV detection. For MS work, this was coupled to a Bruker/Hewlett-Packard 35 Esquire system, using a positive ESI source and the software's default 'smart' settings. Mobile phase used was ACN with $0.25 \%$ formic acid content. This also served as the sample solvent. For analytical LC-MS, a Synergy $150.0 \times 2.0 \mathrm{~mm}, 4$ $\mu \mathrm{m}$ Fusion-RP column was used; flowrate was $0.2 \mathrm{ml} \mathrm{min} \mathrm{m}^{-1}$; detection wavelength was $210 \mathrm{~nm}$. Injections were $5 \mu \mathrm{l}$ of 0.5 $\mathrm{mg} \mathrm{ml}^{-1}$ sample. For semi-preparative HPLC, ACN-THF 90 : 10 and $80: 20 \mathrm{v} / \mathrm{v}$ mobile phases were used for $\mathbf{1}$ and $\mathbf{2}$, respectively. The method used a Synergy $250.0 \times 10.0 \mathrm{~mm}, 10$ $\mu \mathrm{m}$ Fusion-RP chromatographic column; flowrate was $5.0 \mathrm{ml}$ $\min ^{-1}$; detection wavelength was $280 \mathrm{~nm}$. Injections were 100 $\mu \mathrm{l}$ of $300 \mathrm{mg} \mathrm{ml}^{-1}$ sample, filtered before use. Fraction collection was carried out manually or with a Gilson 204 fraction collector in manual mode. Recovery yield was based on percentage of total peak area.

50

\section{ISE membrane preparation and potential measurement}

Membranes were prepared using $250 \mathrm{mg}$ 2-nitrophenyl octyl ether, $125 \mathrm{mg}$ PVC, $6.5 \mathrm{mmol} \mathrm{kg}{ }^{-1}$ host ionophore and 2.7 mmol kg${ }^{-1}$ tridodecylmethylammonium chloride dissolved in 55 dry THF and evaporated slowly. A 'blank' membrane refers to the same membrane cocktail described above, however omitting the presence of an ionophore.

The electrochemical cell was as follows, unless stated otherwise in the text:
$\mathrm{Ag}|\mathrm{AgCl}| 3 \quad \mathrm{M} \quad \mathrm{KCl} \| 0.1 \mathrm{M}$ LiOAc $\|$ sample solution $\mid \mathrm{PVC}$ membrane $|0.01 \mathrm{M} \mathrm{NaCl}| \mathrm{AgCl} \mid \mathrm{Ag}$.

Membranes were conditioned in $0.01 \mathrm{M}$ sodium chloride for $12 \mathrm{~h}$ and deionised water for half an hour prior to ISE titrations, unless stated otherwise. The potentiometric cell was interfaced to a PC using a National Instruments SCB-68 4-channel interface. All ISE measurements were performed in triplicate.

${ }^{1}$ H NMR titrations. 0-3 equivalents of the tetrabutylammonium salts of guest were added to the same $0.5 \mathrm{ml}$ of a 17.5 $\mathrm{mM} \mathrm{CDCl}{ }_{3}$ solution of host and the spectra collected. The association constants were calculated based on the resultant chemical shift changes of an $\mathrm{NH}$ proton using standard equations.

\section{Molecular modelling}

All molecular models and were created using MM2 force field energy minimization. The energy was reduced to a minimum RMS gradient of 0.100 . The software used was Chem3D Ultra 8.0 supplied by Cambridge Scientific Computing, Inc.

\section{Results and discussion}

In ionophore based ISEs, ion-exchangers are required to assist the interfacial transfer of ions from the aqueous phase into the membrane phase, reduce the overall membrane potential, and provide 'trapped' lipophilic counter ions that ensure electroneutrality is maintained during complexation of the target ion by the ionophore.

Similar alkylammonium salts that serve as combined ionophore and ion-exchanger for commercial nitrate analysis also commonly serve as general anion-exchange salts in other anion selective ISEs, complementing additional pre-organised ionophore hosts in ISE membranes. ${ }^{43}$

We used tridodecylmethylammonium chloride as the anion exchanger in the ISE membrane. Initially, membranes were formulated to contain only PVC, plasticizer and the salt and are referred to here from as the blank.

The most common protocols for determining selectivity coefficients for ISEs typically involve pre-exposure of membranes (i.e. electrode filling and/or pre-conditioning solutions) to primary ions prior to analysis. More recently, improved ISE sensitivity and selectivity has been achieved avoiding primary ion contact prior to analysis. ${ }^{46-48}$ For this reason, chloride was used instead of the nitrate exchange salt in the ISE membranes and the internal electrolyte and conditioning solution used was $0.01 \mathrm{M} \mathrm{NaCl}$. The potential change of blank ISEs when immersed in $\log a=-3.0$ (approx. $10^{-3} \mathrm{M}$ ) solutions of a series of anions separately was recorded (a stands for anion activity). The sequence of analysis went from the bottom $\left(\mathrm{SO}_{4}{ }^{2-}\right)$ to the top $\left(\mathrm{SCN}^{-}\right)$of the Hofmeister series. The increasing lipophilicity of the anions meant that the previous anion tested could, theoretically at least, be displaced from the membrane, which maximises the ability to observe Nernstian slopes for all anions tested.

The results were compared to data obtained using the same experimental procedure, with equivalent membranes additionally containing ionophores $\mathbf{1}$ and $\mathbf{2}$. Fig. 1 shows the results. 


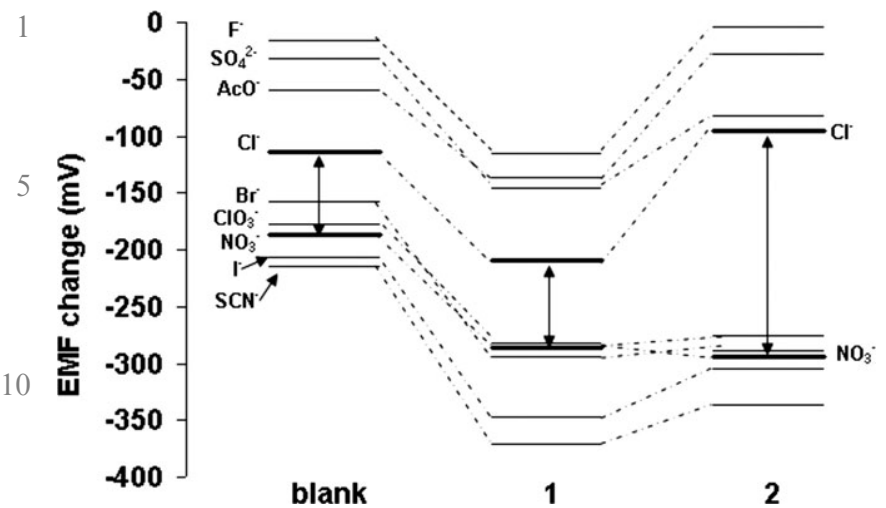

Fig. 1 A graphic illustration of the relative performance of the blank,

151 and 2 in terms of potential change when immersed in a $\log a=-3.0$ solution of the indicated anions. The margin of response between nitrate and chloride is highlighted.

20 The representation of potential data, directly obtained from ISE titration curves (Fig. 1), gives a good semi-quantitative overview of ISE selectivity to compliment formally calculated selectivity coefficients based on Nernstian equations. ${ }^{49}$

All ISEs approximately followed a Hofmeister response

25 order, but a dramatically improved margin of selectivity of nitrate over chloride was observed for $\mathbf{2}$. Table 2 compares the performance of our blank and $\mathbf{2}$ with published data from two nitrate ion-exchange salts supplied commercially (Sigma-Aldrich).

30 From Table 2 it can be seen that the sensitivity (slope) and linear range are clearly larger for our blank than the commercially available materials (despite being chemically very similar exchange salts). We believe that this arises from simply avoiding pre-exposure of membranes to nitrate prior to ana35 lysis.

For membranes additionally containing ionophores $\mathbf{1}$ and $\mathbf{2}$, interesting responses were obtained. There is a general improvement in response to all anions compared to the blank for membranes containing ionophore 1. However, there is no

40 major difference in the margin of potential change between nitrate and chloride, when electrodes are exposed to $\log a=$ -3.0 solutions of each anion separately as seen in Fig. 1 (73 and $77 \mathrm{mV}$ for the blank and $\mathbf{1}$, respectively).

The responses of anions up to chloride in the Hofmeister 45 series (especially $\mathrm{F}^{-}, \mathrm{AcO}^{-}$and $\mathrm{Cl}^{-}$) appear to be ion-ex- change controlled for ISE $\mathbf{2}$, as they are similar to the blank. For the remaining anions in the series, from bromide to thiocyanate, there is a large negative change in potential as in the case of $\mathbf{1}$. The significant consequence of this is that the margin of selectivity between nitrate and chloride has dramatically been improved $(199 \mathrm{mV})$ using ISEs based on calix[4]arene ionophore 2.

Our ISE containing ion-exchange salt and ionophore $\mathbf{2}$ performs favourably compared to commercial nitrate ionexchangers (Table 2) in terms of selectivity, linear range, sensitivity and a LOD improvement of one order of magnitude. It is in terms of selectivity that the additional presence of calix[4]arene ionophore $\mathbf{2}$ has the most impact. ISEs of $\mathbf{2}$ are half an order of magnitude more selective for nitrate over chloride than an ISFET based on commercial B. It is acknowledged that such solid state ISEs often suffer from poor lifetimes, drift and unstable readings. ${ }^{20}$ ISE 2 performs more than one order of magnitude better than commercially available classic nitrate ISEs such as commercial A.

A list of formal selectivity coefficients $\left(\log K_{\mathrm{lJ}}^{\text {pot }}\right)$ for com- 20 mercial B ${ }^{42}$ blank and $\mathbf{2}$ is shown in Table 3.

The data in Table 3 reminds us that all current nitrate ISEs are not strictly nitrate selective but tend to show a strong preference for anions such as iodide.

To further explain the favourably large margin of response between $\mathrm{NO}_{3}{ }^{-}$and $\mathrm{Cl}^{-}$several possible mechanisms occurring in ISEs based on 2 were considered. Firstly, by ${ }^{1} \mathrm{H}$ NMR titrations in $\mathrm{CDCl}_{3}$, the association constants for $\mathrm{NO}_{3}{ }^{-}$and $\mathrm{Cl}^{-}$were determined to be 1150 and $1500 \mathrm{M}^{-1}$, respectively. These values appear quite low but not uncommon for urea based ionophores where competition from self-associative interactions may occur, due to inter- and intramolecular $\mathrm{H}-$ bonding of the ureas. ${ }^{50}$ What is more surprising is the result that 2 shows a stronger affinity for $\mathrm{Cl}^{-}$than $\mathrm{NO}_{3}{ }^{-}$, contrary to intuitive conclusions from potentiometric results. The discrimination revealed by ISE responses are therefore not directly derived from ligand pre-organisation, yet when ionophore $\mathbf{2}$ is omitted as in the case of the blank membrane or ISE 1, the same remarkable selectivity is not observed (Fig. 1).

The response characteristics of ISEs based on $\mathbf{2}$ revealed the next clue. The ISE responded in a Nernstian manner up to chloride but in a super-Nernstian fashion to nitrate and other anions above chloride in the Hofmeister series. Amemiya, Bühlmann and Odashima presented theoretical models and practical examples of how "apparently non-Nernstian"

Table 2 The performance of our ISEs compared to commercially available material, in relation to nitrate sensing

\begin{tabular}{|c|c|c|c|c|}
\hline & Blank $^{a}$ & Commercial $\mathrm{A}^{b}$ & Commercial $\mathrm{B}^{c}$ & Ionophore $2^{d}$ \\
\hline Slope $/ \mathrm{mV}$ decade $^{-1}$ & $-67.7 \pm 1.9$ & $-60.0 \pm 0.9$ & $-51.9 \pm 0.5$ & $-72.8 \pm 0.9$ \\
\hline $\log K_{\mathrm{NO}_{3}^{-} \mathrm{Cl}^{-}}{ }^{\text {pot }}$ & $-1.5(\mathrm{SSM})$ & $-2.1(\mathrm{SSM})$ & $-2.9($ FIM $)$ & $-3.4(\mathrm{SSM})$ \\
\hline Limit of detection (LOD)/M & $1 \times 10^{-6.0}$ & & $1 \times 10^{-5.0}$ & $1 \times 10^{-6.0}$ \\
\hline Repeatability in linear range & 3.3 & & 2.7 & 3.7 \\
\hline
\end{tabular}

(pooled standard deviation \%)

${ }^{a}$ ISEs prepared in our lab, based on tridodecylmethylammonium chloride. ${ }^{b}$ ISE (classical macroelectrode) based on tridodecylmethylammonium nitrate only (Wegmann, 1984). ${ }^{c}$ ISE (ISFET) based on tetradodecylammonium nitrate only (Campanella, 1995). ${ }^{d}$ Blank with additional ionophore 2 ; SSM = separate solutions method; FIM = fixed interference method. 
1 Table 3 Selectivity coefficients, $\log K_{\mathrm{JJ}}^{\mathrm{pot}}$, for commercial B, blank and 2

\begin{tabular}{lcrr}
\hline & Commercial B $^{a}$ & Blank $^{b}$ & \multicolumn{1}{c}{$\mathbf{2}^{b}$} \\
\hline 5 & $0.6^{b}$ & $0.33 \pm 0.01$ & $0.15 \pm 0.02$ \\
$\mathrm{I}^{-}$ & & $0.54 \pm 0.12$ & $0.70 \pm 0.01$ \\
$\mathrm{SCN}^{-}$ & & $-0.13 \pm 0.06$ & $-0.34 \pm 0.02$ \\
$\mathrm{ClO}_{3}{ }^{-}$ & & $-0.50 \pm 0.01$ & $-0.11 \pm 0.01$ \\
$\mathrm{Br}^{-}$ & -1.2 & 0 & 0 \\
$\mathrm{NO}_{3}{ }^{-}$ & 0 & $-1.46 \pm 0.06$ & $-3.41 \pm 0.06^{c}$ \\
$\mathrm{Cl}^{-}$ & -2.9 & $-4.04 \pm 0.11$ & $-5.13 \pm 0.04$ \\
$\mathrm{SO}_{4}{ }^{2-}$ & -3.9 & $-2.16 \pm 0.02$ & $-4.57 \pm 0.07$ \\
$0 \mathrm{AcO}^{-}$ & -2.2 & $-3.19 \pm 0.42$ & $-4.97 \pm 0.07$
\end{tabular}

Note: $\mathrm{I}$ is the primary ion $\mathrm{NO}_{3}{ }^{-}$and $\mathrm{J}$ is the interferant specified. For our ISEs blank and $\mathbf{2}$, the separate solutions method (SSM) was used where $\log a_{\mathbf{I}}=\log a_{\mathbf{J}}=-3.0$. Reproducibility based on three ISE-

15 s. ${ }^{a}$ Fixed interference method (FIM). ${ }^{b}$ Separate solutions method (SSM). ${ }^{c}$ Nernstian response of $-57.2 \mathrm{mV}$ decade $^{-1}$ in the range $10^{-4}-10^{-1} \mathrm{M}$ obtained for $\mathrm{Cl}^{-}$.

behaviour can occur. ${ }^{51}$ It was found that to obtain super-

20 Nernstian responses, a primary and a secondary ion (an interferant ion for example) of the same charge sign must be able to form complexes with the ionophore independently. The primary ion sample activity is increased, whilst the secondary ion activity remains constant. Based on ionophore : ion 25 stoichiometries the resultant slopes could be predicted. Our ionophore clearly fulfils the condition of being able to form complexes with more than one analyte ion. However, the studies reported were based on mixed ion sample solutions, whilst critically our work was based on separate solutions.

30 Membrane impurities and remnant ions from membrane conditioning are not thought to be significant sources of secondary ions. In the absence of a source of secondary ions, this response model has to be discounted.

A further model that is used to explain super-Nernstian 35 response slopes is the Hulanicki effect. ${ }^{48,52}$ Again, this work reported was based on non-specific ISEs i.e. ISEs that can respond to a number of different analyte ions. ISE titrations were carried out starting without any preferred ion present in the membrane or sample phase. As the activity of such an ion

40 is increased in the sample, a super-Nernstian response may be observed. There is due to a particularly large discrepancy in the activity of preferred ion between the sample bulk and the membrane phase boundary. A depletion zone caused by the strong uptake of such ions gives a non-equilibrium situation

45 and a super-Nernstian response. Analogously, the conditioning of ISEs based on $\mathbf{2}$ in 'non-primary' chloride ions may have facilitated such a depletion zone and the nitrate response discussed. To clearly demonstrate that a Hulanicki effect is at play, potentiometric titrations were repeated for $\mathbf{2}$, with the

50 difference that working electrodes were filled and conditioned with $0.01 \mathrm{M} \mathrm{NaNO}_{3}$ instead of $\mathrm{NaCl}$. The response slopes were now much closer to Nernstian at $-53.1 \mathrm{mV}$ decade $^{-1}$ in the range $10^{-5}$ to $10^{-1} \mathrm{M} \mathrm{NO}_{3}^{-}$. As the membrane was conditioned in a primary ion, a depletion zone may not have

55 developed at the membrane-sample interface as some nitrate is present in the membrane at the outset from the conditioning step. A normal equilibrium based ISE response was now observed with increasing activity of nitrate. A selectivity of

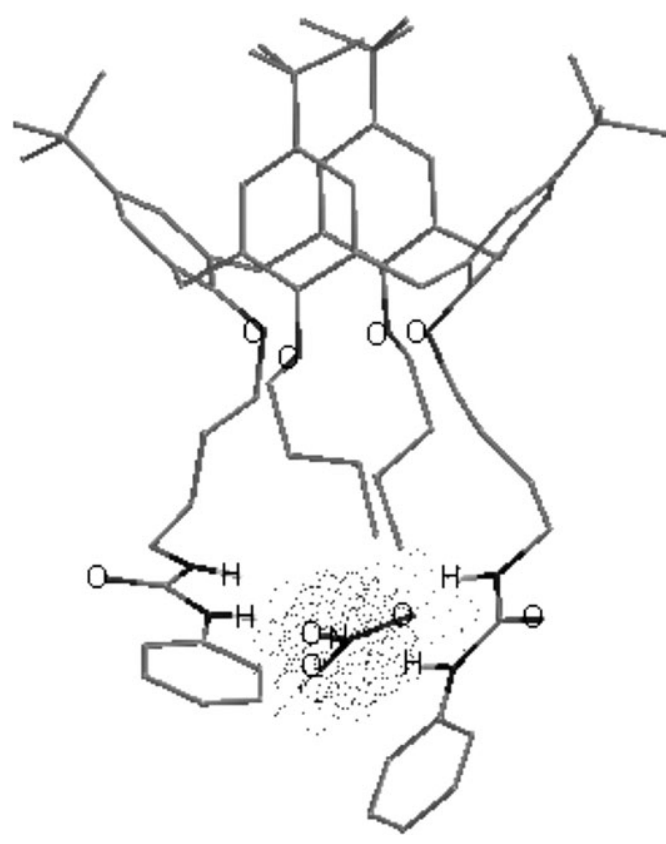

1

Fig. 2 An energy minimised model of 2 complexed to a nitrate anion. Models were generated using Chem3D Ultra 8.0 as described in the Experimental section.

$\log K_{\mathrm{NO}_{3}^{-} \mathrm{Cl}^{-}}{ }^{\text {pot }}=-2.5$ was achieved under these conditions, which is an order of magnitude lower than when conditioning was in $\mathrm{NaCl}$. The choice of pre-conditioning salt is therefore very important in tuning the performance and response characteristics of the ISE of $\mathbf{2}$ presented here.

The main difference between ionophores $\mathbf{1}$ and $\mathbf{2}$ is the length of the alkyl spacer between the calixarene aromatic centre and the lower rim urea groups. 2 possesses longer butyl spacers whilst $\mathbf{1}$ has shorter ethyl spacers. ISEs based on $\mathbf{1}$ (as with the blank) did not achieve the same interesting margin of selectivity of nitrate over chloride as in the case of ionophore 2, showing that ionophore structure and pre-organisation remains a major player in determining a sensor's performance. Fig. 2 shows an energy minimised molecular model of $\mathbf{2}$ and a nitrate anion.

\section{Conclusions}

ISEs containing only ion-exchange salt (blank) and ISEs additionally containing urea-calixarene ionophores $\mathbf{1}$ and $\mathbf{2}$ responded to a series of anions approximately following anion lipophilicity. A proven strategy of avoiding pre-exposure of ISEs to primary ions (nitrate) prior to analysis was used in determining ISE selectivity coefficients. ISEs containing 2 showed an improved response over commercially available ion-exchange salts for nitrate sensing in terms of sensitivity, linear range, LOD and in particular selectivity over chloride, the major interferant of nitrate in environmental water analysis.

We have shown that the favourable response of ISEs based on 2 depends on the sensor pre-conditioning salt, a simple yet important practical consideration. Any practical application of such a system should only be considered if a careful pre-use 
1 protocol is followed. To overcome the selectivity bias due to the super-Nernstian response to nitrate, such a system could be effective where the activity of an interferant, such as chloride, is quite uniform and constant in a sample, whilst a

5 varying primary ion activity is measured. One such example is the open ocean where interferant chloride levels are relatively high yet constant. Here, nutrient levels, including nitrate, vary greatly in tandem with the phytoplankton lifecycle.

ISEs that behave in a non-Nernstian fashion, but where the

10 mechanism is understood, could be useful for sensor optimisation or practical exploitation.

\section{Acknowledgements}

15 We thank Enterprise Ireland, grant code SC/2002/161, Science Foundation Ireland for support under the Adaptive Information Cluster award (SFI03/IN3/1361) and the Environmental Protection Agency, Ireland, funding code EPA2004-RS-AICM4. We thank Aleksandar Radu and Philippe Bühlmann for 20 discussions on ISE theory.

\section{References}

1 G. Eisenman, Glass Electrodes for Hydrogen and Other Cations. Principles and practice, Marcel Dekker, New York, 1967.

252 G. J. Moody, R. B. Oke and J. D. R. Thomas, Analyst, 1970, 95, 910-912.

3 D. Ammann, M. Guggi, E. Pretsch and W. Simon, Anal. Lett., 1975, 8, 709-720.

4 D. Ammann, E. Pretsch and W. Simon, Anal. Lett., 1972, 5, 843-850.

305 U. Fiedler and J. Ruzicka, Anal. Chim. Acta, 1973, 67, 179-193.

6 E. Eyal and G. A. Rechnitz, Anal. Chem., 1971, 43, 1090.

7 A. M. Cadogan, D. Diamond, M. R. Smyth, M. Deasy, M. A. McKervey and S. J. Harris, Analyst, 1989, 114, 1551-1554.

8 T. McKittrick, D. Diamond, D. J. Marrs, P. O'Hagan and M. A. McKervey, Talanta, 1996, 43, 1145-1148.

9 F. Cadogan, P. Kane, M. A. McKervey and D. Diamond, Anal. Chem., 1999, 71, 5544-5550.

10 T. Grady, S. Maskula, D. Diamond, D. J. Marrs, M. A. McKervey and P. O'Hagan, Anal. Proc., 1995, 32, 471-473.

11 M. McCarrick, B. Wu, S. J. Harris, D. Diamond, G. Barrett and M. A. McKervey, J. Chem. Soc., Perkin Trans. 2, 1993, 1963-1968.

12 B. Schazmann, G. McMahon, K. Nolan and D. Diamond, Supramol. Chem., 2005, 17, 393-399.

13 A. Bianchi, K. J. Bowman and E. Enrique Garcia, Supramolecular Chemistry of Anions, Wiley-VCH, New York, 1997.

14 P. D. Beer and P. A. Gale, Angew. Chem., Int. Ed., 2001, 40, 486-516.

15 C. D. Gutsche, Calixarenes, The Royal Society of Chemistry, Cambridge, London, 1989.

4516 R. Ludwig and N. T. K. Dzung, Sensors, 2002, 2, 397-416.

17 D. Diamond and K. Nolan, Anal. Chem., 2001, 73, 22a-29a.

18 A. Ikeda and S. Shinkai, Chem. Rev. (Washington, D. C.), 1997, 97, 1713-1734.

19 F. Arnaud-Neu and M. J. Schwing-Weill, Synth. Met., 1997, 90, $157-164$.
20 D. Diamond and M. A. McKervey, Chem. Soc. Rev., 1996, 25, 15-24.

21 V. Bohmer, Angew. Chem., Int. Ed. Engl., 1995, 34, 713-745.

22 H. Luecke and F. A. Quiocho, Nature, 1990, 347, 402-406.

23 J. J. He and F. A. Quiocho, Science, 1991, 251, 1479-1481.

24 K. H. Lee and J. I. Hong, Tetrahedron Lett., 2000, 41, 6083-6087.

25 D. R. Turner, A. Pastor, M. Alajarin and J. W. Steed, Struct. Bonding (Berlin), 2004, 108, 97-168.

26 K. Lang, P. Curinova, M. Dudic, P. Proskova, I. Stibor, V. St'astny and P. Lhotak, Tetrahedron Lett., 2005, 46, 4469-4472.

27 V. St'astny, I. Stibor, H. Petrickova, J. Sykora and P. Lhotak, Tetrahedron, 2005, 61, 9990-9995.

28 T. Nabeshima, T. Saiki, J. Iwabuchi and S. Akine, J. Am. Chem. Soc., 2005, 127, 5507-5511.

29 V. Stastny, P. Lhotak, V. Michlova, I. Stibor and J. Sykora, Tetrahedron, 2002, 58, 7207-7211.

30 J. Budka, P. Lhotak, V. Michlova and I. Stibor, Tetrahedron Lett., 2001, 42, 1583-1586.

31 K. C. Nam, S. O. Kang, H. S. Jeong and S. Jeon, Tetrahedron Lett., 1999, 40, 7343-7346.

32 L. A. J. Chrisstoffels, F. de Jong, D. N. Reinhoudt, S. Sivelli, L. Gazzola, A. Casnati and R. Ungaro, J. Am. Chem. Soc., 1999, 121, 10142-10151.

33 J. Scheerder, J. P. M. vanDuynhoven, J. F. J. Engbersen and D. N. Reinhoudt, Angew. Chem., Int. Ed. Engl., 1996, 35, 1090-1093.

34 J. Scheerder, J. F. J. Engbersen, A. Casnati, R. Ungaro and D. N. Reinhoudt, J. Org. Chem., 1995, 60, 6448-6454.

35 J. Scheerder, M. Fochi, J. F. J. Engbersen and D. N. Reinhoudt, J. Org. Chem., 1994, 59, 7815-7820.

36 N. Pelizzi, A. Casnati, A. Friggeri and R. Ungaro, J. Chem. Soc., Perkin Trans. 2, 1998, 1307-1311.

37 H. K. Lee, H. Oh, K. C. Nam and S. Jeon, Sens. Actuators, B, 2005, 106, 207-211.

38 K. P. Xiao, P. Buhlmann, S. Nishizawa, S. Amemiya and Y. Umezawa, Anal. Chem., 1997, 69, 1038-1044.

39 M. J. Berrocal, A. Cruz, I. H. A. Badr and L. G. Bachas, Anal. Chem., 2000, 72, 5295-5299.

40 S. W. Jeon, H. Y. Yeo, H. S. Jeong, J. M. Oh and K. C. Nam, Electroanalysis, 2003, 15, 872-877.

41 D. Wegmann, H. Weiss, D. Ammann, W. E. Morf, E. Pretsch, K. Sugahara and W. Simon, Mikrochim. Acta, 1984, 3, 1-16.

42 L. Campanella, C. Colapicchioni, G. Crescentini, M. P. Sammartino, Y. Su and M. Tomassetti, Sens. Actuators, B, 1995, 27, 329-335.

43 R. W. Cattrall, Chemical Sensors, Oxford University Press, Oxford, 1997.

44 A. C. Duxbury and A. B. Duxbury, An Introduction to the World's Oceans, Wm. C. Brown Publishers, Dubuque, 1997.

45 B. Schazmann, S. O'Malley, K. Nolan and D. Diamond, Supramol. Chem., 2006, 18, 515-522.

46 M. A. Pineros, J. E. Shaff, L. V. Kochian and E. Bakker, Electroanalysis, 1998, 10, 937-941.

47 E. Bakker, Electroanalysis, 1997, 9, 7-12.

48 E. Bakker, Anal. Chem., 1997, 69, 1061-1069.

49 E. Bakker, E. Pretsch and P. Buhlmann, Anal. Chem., 2000, 72, $1127-1133$.

50 S. Nishizawa, P. Buhlmann, M. Iwao and Y. Umezawa, Tetrahedron Lett., 1995, 36, 6483-6486.

51 S. Amemiya, P. Buhlmann and K. Odashima, Anal. Chem., 2003, 75, 3329-3339.

52 M. Majzurawska, T. Sokalski and A. Hulanicki, Talanta, 1988, 35, 281-286. 


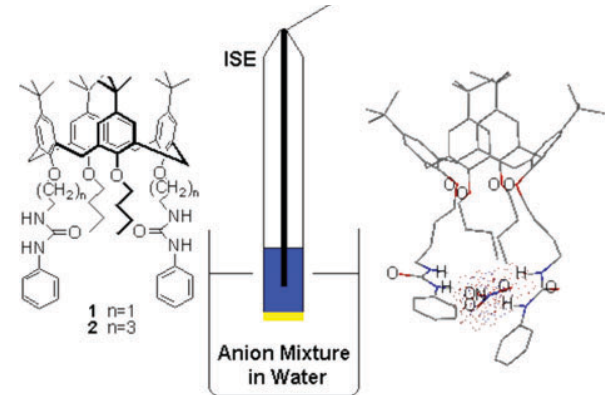

Improved nitrate sensing using ion selective electrodes based on urea-calixarene ionophores

Benjamin Schazmann and Dermot Diamond

Improving the selectivity of nitrate over chloride in waterbased anion sensing with the aid of urea-calix[4]arene ionophores.

Please check this proof carefully. Our staff will not read it in detail after you have returned it. Translation errors between word-processor files and typesetting systems can occur so the whole proof needs to be read. Please pay particular attention to: tabulated material; equations; numerical data; figures and graphics; and references. If you have not already indicated the corresponding author(s) please mark their name(s) with an asterisk. Please e-mail a list of corrections or the PDF with electronic notes attached -- do not change the text within the PDF file or send a revised manuscript.

Please bear in mind that minor layout improvements, e.g. in line breaking, table widths and graphic placement, are routinely applied to the final version.

Please note that, in the typefaces we use, an italic vee looks like this: $v$, and a Greek nu looks like this: $\nu$.

We will publish articles on the web as soon as possible after receiving your corrections; no late corrections will be made.

Please return your final corrections, where possible within $\mathbf{4 8}$ hours of receipt, by e-mail to: proofs@ rsc.org

Reprints - Electronic (PDF) reprints will be provided free of charge to the corresponding author. Enquiries about purchasing paper reprints should be addressed via: http://www.rsc.org/Publishing/ReSourCe/PaperReprints/. Costs for reprints are below:

\begin{tabular}{|lrr|}
\hline \multicolumn{2}{|l|}{ Reprint costs } & \\
\hline No of pages & Cost for 50 copies & Cost for each additional 50 copies \\
\hline $2-4$ & $£ 180$ & $£ 115$ \\
$5-8$ & $£ 300$ & $£ 230$ \\
$9-20$ & $£ 600$ & $£ 480$ \\
$21-40$ & $£ 1100$ & $£ 870$ \\
$>40$ & $£ 1700$ & $£ 1455$ \\
\hline \multirow{2}{*}{ Cost for including cover of journal issue: } & & \\
£50 per 50 copies & \\
\end{tabular}

Queries are marked on your proof like this Q1, Q2, etc. and for your convenience line numbers are indicated like this 5, 10, 15, ... 


\begin{tabular}{|c|c|c|}
\hline $\begin{array}{c}\text { Query } \\
\text { reference }\end{array}$ & Query & Remarks \\
\hline & NO QUERY & \\
\hline
\end{tabular}

